\title{
The Philosophical Bases of the Pedagogical Views of V. F. Odoyevsky
}

\author{
Anna Martseva \\ Peoples’ Friendship University of Russia \\ Moscow, Russia \\ martseva@mail.ru
}

\author{
Diana Sivakova \\ Peoples' Friendship University of Russia \\ Moscow, Russia \\ dv.sivakova@gmail.com
}

\begin{abstract}
The paper unveils the interrelationship existing between V. F. Odoyevsky's pedagogy and his philosophical ideas. The philosophical and pedagogical legacy of the thinker is of a considerable interest as one of the most developed in the history of Russian thought in the first half of the 19th century in the models for the construction of a program of education in the wake of the romantic 'organicistic' education. The author demonstrates that the pedagogical dominant in Odoyevsky's philosophical worldview forms very early; the analysis of the development of his philosophical views since the 1820 s reveals an intrinsic link between the pedagogical orientation of his mindset and the philosophical reflection on cultural, linguistic and knowledge issues. This link is also maintained in the works of the 1830s and 1840s, when Odoyevsky's observations in the field of theory and practice of education become isolated in a disciplinary sense from the philosophical corpus of his ideas.
\end{abstract}

Keywords-Odoyevsky; education; up-bringing; pedagogy; ideal language; nationality; culture; lovers of wisdom (lyubomudry)

\section{INTRODUCTION}

The pedagogical legacy of V. F. Odoyevsky (1803/041869 ) is currently the subject of research interest on the part of educators, psychologists and philosophers, not only as a historical 'illustration' of the fundamental issues of theory and practice in the educational process, but also as an original system of views on the problem of education possessing a certain heuristic potential.

The contemporary approaches to the problem of upbringing and teaching a subject are largely dictated by the need to overcome the legacy of the ideology of the Modern Times and the Enlightenment in the part in which the individual and society act as the object of influence. However, it is in this era of the Modern Times and the Enlightenment that the foundations for the separation of pedagogy into an independent scientific discipline are laid, in which two necessary components are present: the theoretical, as the "philosophy of education", and the practical. In the early stages of the development of pedagogical science, the vectors of pedagogy are already differently oriented. One proceeds from the concept of a person as the bearer of universal consciousness, while the other is centered on the individual and personal beginning of each person, not reducible to his reason, but also not contradicting him. Since the 20th century, the dominant direction in pedagogy has been the so-called "personality-oriented" upbringing and training, which is based on the creative and cognitive activity of an individual. This humanistic orientation of modern pedagogy, however, is genetically related to its initial stage, since, even the most loyal advocates of the cult of reason could not deny the great importance of individual features, not so much in theory as in the practice of education. However, as in the 17 th -18 th centuries, in the 21 st century, the question remains topical: Is it possible to reconcile this ideal of personal orientation and the need to build a system for the upbringing and education of people? In other words, is it possible to reconcile the subtle art of personal upbringing that appeals to the individuality of the teacher and the student, and the rigid technology of mass upbringing and education aimed at satisfying public and even state needs?

The philosophical and pedagogical views of Odoyevsky, one of the first, in the history of Russian thought, example of a comprehensive theoretical and practical solution to the problem of education in the wake of the romantic "organicistic" pedagogy is being shaped as an antithesis to the dominant ideological orientation toward upbringing as the shaping of the human personality from the outside on a strict plan [1] [2]. The 'core' of Odoyevsky's pedagogical theory is linked to the understanding of the process of education as a form of self-upbringing that cannot be definitively formalized, but at the same time must be consistent with the logic of human development and the logic of the development of society and the nation. It should be noted that despite their interrelated nature, Odoyevsky's pedagogical ideas are widespread in a number of both completed works and sketches, very diverse in genre relations. Due to this circumstance, Odoyevsky's pedagogical legacy can be reconstructed precisely as a system only in the context of his general philosophical views. Representatives of pedagogical science, who, as a rule, entailed an insufficiently careful attitude to the philosophical foundation of Odoyevsky's pedagogical ideas, made the attempts of this kind of reconstruction [3]. With regard to historians of philosophy, if there is a sustained interest in the legacy of Odoyevsky, his practical pedagogical activities have traditionally been conceived as a certain side-trend to his creative biography, not having a direct relationship to the historical and philosophical problems. Thus, the identification of a direct relationship between the corpus of 
the philosophical (anthropological, epistemological and philosophical-historical) representations of Odoyevsky and his pedagogical activity in its theoretical and practical dimensions is a task equally important for both historicalphilosophical science and pedagogy.

\section{THE WORK OF V. F. ODOYEVSKY IN THE CONTEXT OF THE RUSSIAN CULTURE OF THE FIRST HALF OF THE $19^{\mathrm{TH}}$ CENTURY}

Prince V. F. Odoyevsky turned out to be a contemporary of the epoch-making events in Russian history (the war with Napoleonic France of 1812, the Decembrist Revolt in 1825, and the Emancipation Reform in 1861). An heir of the aristocratic family going back to Rurik, very gifted, welleducated and purposeful, Odoyevsky has naturally appeared in the constellation of the creators of the "Golden Age" of Russian culture. Graduating with honors from the Moscow University College, he actively joins the circle culture of the $1820 \mathrm{~s}$, tries his hand at publishing and journalism, and at the same time studies philosophy, literature, music and natural sciences. The maxims in the spirit of the French Enlightenment tradition initially acquired by Odoyevsky in the college (encyclopaedism, belief in Reason and the inviolability of its laws, interest in mysticism) in the 1820 s look 'archaic' [4]. However, Odoyevsky does not discard them definitively, but transforms on the basis of the ideas of ro0manticism, which at that time had taken possession of the minds of educated youth. As a result, Odoyevsky sees the limitations of the encyclopaedic form of the organization of knowledge, which, although it lacks an inner unity, he still maintains confidence in the need for the all-round development of human cognitive and creative abilities. Odoyevsky positively and definitively deals with the question of the need for a philosophical basis for the implementation of "higher synthesis". Even in his later works, ironically, on the very term ("imaginary encyclopaedism"), Odoyevsky nevertheless once again emphasizes the conventionality of the existing differentiation of scientific knowledge, which has the right to exist only as an intermediate link on the way to whole knowledge: "Until a universal science has been developed, it is necessary that each person, having discarded one's scholastic swaddlingclothes, formed his or her own special science, for the circle of his activity, commensurate with the space of his understanding, a science unnamed, which cannot be reduced to any conditional heading" [5]. This striving for the wholeness of cognition, which was a general setting of Russian philosophical thought based on Western romantic sources, takes on Odoyevsky a special character, since he not only postulates the principle of wholeness, but also consistently implements it throughout his life. Public service, philosophical studies, literary experiments, music theory, pedagogy are far from a complete list of what Odoyevsky succeeded in combining without harming each of these areas and without compromising his convictions. This ideal of the integrity of knowledge and life was not available to all contemporaries of the thinker, it is enough to recall the example of Count S.S. Uvarov, who, in his theoretical constructs, was close to Odoyevsky, but circumstances often forced him to take practical steps, obviously contrary to the theory.

\section{The Pedagogical Dominant In the Philosophy OF ODOYEVSKY AND THE CRITICISM OF CULTURE}

Like many representatives of the post-war generation, Odoyevsky enters the realm of philosophy through criticism of culture. The search for a national and cultural identity, the restriction of the universalist orientation through the recognition of the leading role of the individual beginning of each subject of history expressed in the principle of 'nationality' (narodnost'), are the main lines of philosophy of the history and philosophy of the culture of the 1920s-30s in Russia [6]. Not surprisingly, the very first (and most ambitious) task of young Odoyevsky, corresponding to the general mood of the era, is to overcome the borrowed nature of Russian culture and the philosophical awakening of Russia. Having headed the "Society of Wisdom-Loving" (Obshchestvo Lyubomudriya), Odoyevsky and his associates draft a transformation of Russian culture on the basis of philosophy ("absolute theory") in the spirit of Schelling. It is characteristic that the Wisdom-lovers (Lyubomudry), unlike the Decembrists, assumed exclusively educational measures of influence as the only expedient ones. Neither the society as a whole, nor the individual can be changed by direct external influence, the more so if it is revolutionary, since they have an organic nature. The lyubomudry's program has a pronounced pedagogical dominant, and the lyubomudry unanimously perceive themselves as educators and enlighteners of the Russian culture. For example, poet and philosopher D.V. Venevitinov in an article of 1824, "What is written by a pen cannot be cut out with an axe" writes about "that ... it is the duty of everyone, as far as one's strength and one's abilities, to promote the common good in the circle destined for him by fate" [7]. The high level of "education" and "moral capacity", in the thought of Venevitinov, imposes on them the highest measure of responsibility for the destiny of Russia. Odoyevsky shares this view of Venevitinov, very characteristic of his time, quite fully. However, it is Odoyevsky who makes an attempt to transfer the concept of "service" from the sphere of ideological rhetoric into the realm of philosophy. Odoyevsky is an opponent of the utilitarian interpretation of this promotion of the common good. What is the duty of a philosopher, according to Odoyevsky? Not to have his ideas become a method of practical activity. The nation is not an object, but a subject, and therefore, this subject can be improved, and not as a work of art, but as other, as a person. According to Odoyevsky, these ideas were inspired by the philosophy of Plato, who demonstrated the essence of Socrates' pedagogical maieutics. For Odoyevsky, the Russian nation is the slave boy from the "Meno" dialog, who, if he so desires ("philosophical awakening") and correct guidance (the "absolute theory") can attain any height. Thus, already in the 1820 s, Odoyevsky is placing the problem of upbringing at the forefront (although, so far, it is primarily in the form of abstract arguments about the upbringing of the nation) and is not detracting from the chosen strategy for the rest of his days. 
For Odoyevsky, the state of being is organic, not mechanistic. Therefore, the philosopher must liken himself or herself to an educator, not a watchmaker. Even the romantic theory of genius and insanity, which repeatedly attracted Odoyevsky's attention (for example, in the essays "Russian Nights", "The Science of Instinct", "Psychological Notes"), did not escape this pedagogical connotation [8].

\section{The Problem of THE Universal LANGUAGE}

Odoyevsky also manifests this kind of consistency in another direction key to his creative work - the search for the optimal means of the expression of thought ("ideal language"). He first discovers this problem for himself during his studies at the college, when he writes under the guidance of Professor I.I. Davydov an academic essay, which is based on the ideas of J.M. Degérando [9]. Interpreting Degérando, Davydov linked the progress of science with the development language. Odoyevsky is mastering and further developing this idea by analyzing the possible strategies for the development of a universal language (from the combinatorics in the spirit of Leibniz and Lull to the "inner language" in the spirit of the mystical traditions of J. Pordage, L.C. de Saint-Martin and F.X. von Baader, as well as the romantic concept of creating an "ideal language" through the synthesis of philosophy and the arts.) Ultimately, however, the many years of pedagogical practice make Odoyevsky doubt not so much the possibility as the need for universal linguistic form. Pedagogical maieutics require a special, unique form of communication for the pupil and the teacher, which, in the application to culture and pedagogical science as a whole, sounds like the requirement of "the nationality". Therefore, the linguistic reflection of the late philosophical and pedagogical works of the thinker is designed to justify the appropriateness of a person-oriented language or, more precisely, a person-oriented way of communication. Thus, Odoyevsky's philosophical understanding of culture and history turns out to be in harmonic unity with the philosophy of language in large part due to the pedagogical orientation of his research.

\section{ODOYEVSKY'S PHILOSOPHY OF EDUCATION}

The philosophy of education as a separate direction in the works of Odoyevsky has been around since the 1830s, when he is involved in philanthropic activities, organizing shelters, and, a little later, schools and educational projects for peasants.

An important role in the development of the theory of education and didactics is played by Odoyevsky's epistemological foundation, which he seeks to clarify by combining his original philosophical intuitions and attitudes with the results of his own pedagogical observations, and (especially importantly) with the sources on "modern pedagogy" available to him. He is particularly interested in works devoted to the so-called "initial pre-school education," since it is in this period that the very source of knowledge, which he dreamed of while still a member of the "Society of Wisdom-Loving", can be found. Odoyevsky shows extraordinary erudition, analyzing the work of J.H. Pestalozzi, J.-B. Girard, J. Jacotot, H. Stephanie, R.
Lambruschini, Ye.O. Gugel, and others. In his work of 1844 "An Essay on Pedagogical Methods in the Initial Education of Children", while reinforcing his own observations by the authority of the scientists he respects, Odoyevsky quite clearly speaks in favor of the theory of "innate ideas," (or "pre-knowledge") but not in the Cartesian vein [10]. He is convinced that they are the essence of "the living product of our spiritual-corporeal organism" and are present in a simpler form in animals, plants and even minerals [10]. Odoyevsky's argument in this case refers us to his natural philosophical studies, which, as before, played a fundamental role in his philosophical worldview. On the basis of the new data, Odoyevsky has already fully justified the need for the development of organicistic pedagogy, in which all areas of the thinker's activity are in demand.

The deduction of "innate ideas" into the sphere of "conscious understanding" and giving them harmonic unity for the realization of the basic needs of a concrete human person and humanity as a whole (the needs of love and truth) constitutes the highest goal of pedagogy. However, Odoyevsky's path to this goal is extremely difficult and painstaking. "Do not impart knowledge to a person, but try letting him develop the ability to reach for it himself" - this is the highest limit of pedagogy ...," Odoyevsky writes [10]. Philosophical and pedagogical maieutics, which focuses not so much on the algorithms of the process of upbringing and education (although Odoyevsky has thought this side to the smallest detail), but how much the personal contribution of the student and mentor implies the service of a mentor and teacher to the cause of human education and, in the potency of, humanity.

The personal orientation of Odoyevsky's philosophical and pedagogical theory is unquestionable, but it is very far from that of modern educational and educational processes. Odoyevsky requires service and self-improvement primarily from mentors and teachers. Relying on the child's need for a holistic vision of the world, Odoyevsky draws here the romantic ideal of synthesis of philosophy, sciences and arts, which the mentor should actually seek to have sufficient competence, as well as a high level of empathy and morality, which ultimately turns both theoretical and practical side of pedagogy into an art for the elect.

\section{CONCLUSION}

The article in general outlines the relationship between Odoyevsky's pedagogical theory and practice and his philosophical ideas, including the earliest. In the worldview of the thinker, beginning with the early 1820 s, the ideas and intuitions that are keys to his creative work are formed, albeit not in their final form. An analysis of the elements of this philosophical basis (the desire for integrity of knowledge, the development of the problem of the "ideal language", the requirements of "national spirit" in all spheres of culture, the organicist interpretation of the process of education) shows not the external but their immanent interconnection. From a formal point of view, the creative work of V.F. Odoyevsky does not in itself constitute a system. The diversity of his scientific interests and practice, some element of discreteness in his philosophical research combined with the fragmented 
nature of his works all constitute the circumstances that problematize the process of reconstructing Odoyevsky's intellectual heritage. We are convinced that the most promising direction meeting the expectations of representatives of many scientific disciplines is overcoming the highly specialized demarcations of his ideas and texts and transitioning into interdisciplinary interaction in the process of reconstructing Odoyevsky's views.

\section{REFERENCES}

[1] I.V. Grebeshev, "Becoming of Philosophical Pedagogics and Philosophy of Education of Personalistic Type in Russia in the XIX Century", in Electronic Scientific Edition Almanac Space and Time: 'The Space and Time of Education', 8.12015 . Web. $\quad<2227-9490 \mathrm{e}-$ aprovr_e-ast8-1.2015.22>. (In Russian).

[2] N. Cornwell, V.F. Odoevsky. His Life, Time and Milieu. Bloomsbury Publishing, 2015.

[3] M.Ya. Struminsky, "V.F. Odoyevsky and his pedagogical ideas", in Odoyevsky V.F. Selected Pedagogical Writings. Moscow, 1955. (In Russian).

[4] P.N. Sakulin, From the history of Russian idealism: V.F. Odoyevsky as a thinker and writer, vol. 1, parts 1-2. Moscow, 1913. (In Russian).

[5] V.F. Odoevsky, Selected Pedagogical Writings. Moscow, 1955, p. 170. (In Russian).

[6] A. Koyré, Philosophy and National Problem in Russia at the Beginning of the 19th Century. Moscow, 2003. (In Russian).

[7] Russian Essays on Aesthetics of the first third of the 19th century, vol. 2. Moscow, 1974, p. 610. (In Russian)

[8] N.V. Sacré, "Between E.T.A. Hoffmann and F. Schelling: Medical Discourse in the Creation of V.F. Odoyevsky", in Culture and Text, 2017 (28), no. 1, pp. 6-24. (In Russian).

[9] A.A. Krotov, "The Principles of the Analysis of the History of Philosophy in the Interpretation of "Ideologists" School (Degerando)", History of Philosophy, 2017, vol.22, no.1, pp. 5-14. (In Russian).

[10] V.F. Odoyevsky Selected Pedagogical Writings. 